\title{
Reality Study of Managerial Ability of Managers of Community Learning Center (CLC)
}

\author{
Abdul Karim Halim \\ Non Formal Education Department, University of Ibn Khaldun Bogor \\ fkipuikabogor@gmail.com
}

\begin{abstract}
This research was motivated by previous research about Framing Strategies for Achieving Average Length School through Non-formal Education. The result shows that Average Length School is still very low, at 8.24. So that raises the question of the researcher; How Community Learning Center Impact Reality of Average Length School? Based on that question, the researcher needs to do a study about the reality of managerial ability of managers of community learning center. The aim of this study is to analyze; managerial capability of managers of Community Learning Centre is expected to make the program enhancement Average Length. This study used a qualitative approach with descriptive methods. The urgency of this research expected to be consideration in taking decision makers correlated with guide for Community Learning Center.
\end{abstract}

Keywords-Managerial Capabilities, CLC, Average Length of school

\section{INTRODUCTION}

Non-formal Education in the implementation of its programs have different types of educational units, as expressed in Article 26, paragraph 4 of Law No. 20 of 2003 on National Education System, which consists of courses, training institutes, study groups, community learning centers, and majlis ta'lim and similar educational unit. [1] Education units, the breadth targets and somewhat educational units are built depending on the needs of local communities and the ability of managers to understand the kinds of educational units and non-formal education programs required by the community.

Community Learning Centers have a strategic position when it is used to develop non-formal education's units as a means to improve the quality of the nation. Based on Government Regulation No 17 Year 2010 which was renewed by Government Regulation No. 66 Year 2010 on the Management and Delivery of Education in article 105 paragraph (2) states: "Community Learning Center may operate; 1. Early Childhood Education, 2. Education literacy, 3. Educational equality, 4. Empowerment of women education, 5. Life skills education, 6. Youth
Education, 7. Education workmanship and / or, 8. Other educational that needed. [2]

Speaking on the managerial skills of managers CLC will not be separated from the presence of educators and education in CLC, the educators are generally defined as those who are involved and responsible directly in the process of implementing or community activities, generally composed of three types, namely; 1 . Teacher, 2. Program Manager, and 3. The manager of CLC. [3]

Complexity of the programs carried out by CLC, as important as the tasks carried out by formal education unit, so that the managers PKBM require measurable competence, as defined by the Development and Learning Activities Center Jaya Giri; "The Managers of CLC must have 3 (three) competency, namely; 1. Personal Competence, 2. Professional Competence, 3. Social Competence3), then the Ministry of National Education, added: 4. Pedagogic Competence. [4]

Based on observations and reports from the Education Authorities at Bogor District first semester of 2016, most of the CLC in Bogor has made great efforts to improve the quality of human resources, through literacy programs, educational equality, early childhood education, life skills education and a public reading as well as the units of other non-formal education. However, in practice they have not been able to organize education units in accordance with national standards of education, it is because most of the CLC has not been able to meet the standards as determined by Government Regulation No. 32 Year 2013 on National Education Standards, including graduate competence standard, content standard, standard process, educator and education personnel standard, facilities and infrastructure standard, management standard, financing standard, and educational assessment standard [5]

Currently, all managers CLC at Bogor District required to be able to make the improvement of the 
Human Development Index at Bogor District successful, which in 2014 reached 74.35 out of 80.00 [6], with the strategy of the National Movement Acceleration Completes Compulsory Basic Education 9 Years and Eradication of Illiteracy and Program Improvement School Average Length of Service Through Non-formal Education, as the two determinants besides indicators Income per capita and life expectancy.

Based on the framework above, this research is conducted in order to find the learning needs of managers CLC to improved service quality and learning outcomes in accordance with national education standards. We hope this research can provide benefits to reveal empirically about the various management of CLC, CLC minimum standard management and efforts to formulate a quality conceptual design CLC management that people need, especially at Bogor District.

The General purpose of this research is to get a clear picture of the reality of managerial capability of managers of CLC at Bogor District to improve service quality and yield learning process according the national standards of education, whereas in particular the goal of this study was to analyze;

- Capacity of the managers of Community Learning Center at Bogor District.

- Educators Competence and Educational Community Learning Center in Bogor District.

- Managerial ability of managing Community Learning Center, to improve service quality and learning outcomes of students based on national standards towards raising the average length of school in Bogor District.

\section{LITERATURE REVIEW}

\section{A. The concept of Community Learning Center.}

As a unit of Non-formal Education, CLC has the task to providing educational services to people who are not affordable and not served by formal education. Community Learning Center (CLC) is a container in which the entire community learning in order to increase knowledge, skills/expertise, hobby, or talent managed and organized by the community itself. CLC is a medium to prepare citizens to be more selfsufficient to fulfill their needs, including in terms of increasing their income.

The establishment of CLC is to trigger and temporary, the people themselves who have the authority to develop it further, so that the approach in
CLC program is called community-based education with the hope can be used as a foothold and starting point for all development components to empower the potentials that exists in society. There are three important objectives in the development of Community Learning Centre, namely: a. Empower communities to be self-sufficient, $b$. improving the quality of life in terms of both social and economic, c. Increased sensitivity to the problems that occur in their environment so they can solve these problems. Sihombing said that; Intention of institutionalization Community Learning Center is to explore, grow, develop, and exploit the existing potentials in the society itself. In the sense of empowering all potential and existing educational facilities in the village as a community efforts directed to support poverty reduction, with the principle of development in order to democratize education. Through education conducted in CLC community is expected to empower themselves [7]. Fasli Jalal according to Mustafa Kamil mentioned the functions of CLC are: a. as a center of various potentials that exist and thrive in society, $b$. Reliable source of information for people in need of functional skills, c. Points exchanging various knowledge and functional skills among citizens. [8]

Basic characteristic which should be the reference of institutional development community learning activity centers are: a. learning society, b. learning exchange, c. information and knowledge center or library's society, d. as central meeting various levels of society, e. community research center especially in the development of non-formal education8). The basic principle that could be referred as development and arrangement community learning activity center programs, are: a. shall extend learning so that people have more opportunities to develop experience about knowledge, skill, attitude and value which related to ethics, aesthetic, logic and kinesthetic at the time of learning, $b$. having the balanced principle which every single competence developed in CLC must be achieved through an adequate allocation of time for a learning process that is effective, c. relevant, because every program associated with the preparation of the learners to improve the quality of life by chance, experience, and training in acting, behave responsibly in realizing the maturity of thinking, $d$. being able to put forward the concept of differentiated.

To support those principles, there are some standard: a. quality of human resources that carries the program, b. ability to cooperate with certain parties, c. 
ability of the learning source, d. residents/learners who are interested and need education to develop themselves e. facility representative program, f. community participation, g. instrument control (supervision, monitoring, and evaluation ), h. another carrying capacity; model to be developed, material, module, which corresponds to the needs of learning, i. budget, j. maintenance program, $\mathrm{k}$. development program [8].

The Indonesian national education system divided into formal education subsystem, Non-formal subsystem, informal education subsystem. The third educational subsystem were mutually reinforcing in operating in order to accelerate the national education targets which would eventually strengthen an objective of national development. Non formal education is a process that lasts all ages that anyone get value, attitude, skill and knowledge arising from experience, environmental influences included is the family life, relationship with neighbors, employment and the environment, market, library and the media. Meanwhile non-formal education is organized and systematic activity, outside the established school system, conducted independently or an essential part of wider activities, deliberately made to serve specific learners in achieving learning goals.

In Article 26 Paragraph (1) of Law Number 20 Year 2003 on National Education System, said; Nonformal education organized for communities in need of educational services that act as substitutes, enhancer, and/or complement formal education in order to support lifelong education1). The third function of non-formal education can take place at one of the centers of education or may also take place in time and place together so that a person and/or group of people get the information, education and training, as well as guidance or counseling in accordance with the needs of learning, with the intention to improving and develop knowledge (cognitive), attitudes (affective) and/or skills (Psychomotor) as well as the values of culture and religion that enables use by individuals and/or groups involved in the interaction within the family, community, work environment and even the country effectively and efficiently [9].

Nonformal education stand on the principle of needs, the principle of lifelong education, the principle of relevance to the development and the principle of insight into the future. The principle of needs is the gap between the existing conditions and is being experienced by a person and/or group of people with the condition of the desired/expected by a person and/or group. The principle of needs can be classified into human needs, education needs, and learning needs [9].

Lifelong education is a conscious effort that fosters lifelong learning. Since the beginning of its birth, issues of Non-formal Education driven by the notion that formal education is not able to balance the development of science and technology, including the development of society in it, so it takes the education system more flexible, able to change according to the needs of development and the times quickly. The educational system in question is non-formal education system. The function of non-formal education is to develop the human resources (Human resources development) as a subject of community development so that they have a culture of organization (community organization) to continue developing the economic value (economic development), both in the urban and rural community. [9].

\section{B. Nonformal Education Program Management Concept.}

Hersey and Blanchard, define management; "Management as working with and through individuals and groups to accomplish organizational goals".[10] Stoner, define management: "Managements is the process of planning, organizing, leading and controlling the Efforts of organizing members and of using all other organizational resources to Achieve stated organizational goals" [10]

Both definitions mentioned above implies the management of a series of activities to plan, organize, move, control and develop all efforts to set up and use human resources, facilities and infrastructure efficiently and effectively to achieve organizational goals that have been set. In developing efforts, as mentioned above there is a renewal or innovative changes.

In this research is meant by management is an effort in implementing management functions in the administration of the various activities undertaken by the Community Learning Center that includes; planning, organizing, mobilization, training, assessment and development to achieve the goals set.

\section{Methodology.}

This research used a qualitative approach with descriptive method used to investigate and solve the existing problems in the present [10], which studies 
the reality of managerial abilities of managers of Center Learning Community at Bogor District, with 62 samples managers CLC out of the 208 CLC at Bogor district. This research used purposive sampling techniques, the technique of sampling with particular consideration [11].

\section{RESUlTS AND DISCUSSION}

From the results of data processing obtained information that the majority $(79.03 \%)$ of respondents aged between 36-55 years old, or are in a position very productive age, more than half of respondents $(59 \%)$ work as civil servants, based on interviews and observations obtained data that those who become managers CLC majority of civil servants working in the field of Non-formal Education or at least have worked on this section. This condition is well recognized by officials at the Department of Education Bogor and want repaired so that one day will be born CLCs tough and qualified, its manager work more professionally and based on the competencies required by law so that being able to create the CLC that has a standard approaching equality with formal education, by giving scholarships to 58 managers of CLC on Non-formal Education Program FKIP - UIKA Bogor in the academic year 2016-2017.

In line with the mission of Bogor Regency Government to improve the Human Development Index Bogor regency in 2020 with an increase in the average length program of the school through nonformal education. Here are the results of data management on managerial skills of the managers of CLC, those are;

Based on the data obtained more than half $(67.73 \%)$ of respondents said they already have a complete program planning, and more than half $(67.74 \%)$ of respondents also stated that they have plans that are based on the result of cooperation among all components in the CLC, but more than half $(64.51 \%)$ of respondents stated that they did not invite public participation in the preparation of the work program, even though the entire $(100 \%)$ of respondents agreed that the learning program which they set based on the learning needs of the community.

Hereinafter also known that the entire $(100 \%)$ of respondents said they already have a complete management, but a large part $(77.42 \%)$ of them doubts the ability of the management to cooperate in teams.
The majority $(87.10 \%)$ of them also doubt the ability of managers to perform management turnover CLC regularly and periodically, although the entire $(100 \%)$ of respondents believe that their own division of labor. This may be caused by the level of education the majority (77.42\%) of respondents who do not graduate, so that there are likely effect on their ability to lead and manage CLC, that most $(80.65 \%)$ of respondents expressed doubt on their ability to manage with good learning process, while in other cases, the majority $(76.74 \%)$ stated their own personal competence and each more than half $(51.61 \%)$ of respondents said they have pedagogic competence, $62.90 \%$ of respondents said they already have professional competence, but more than half $(51.62 \%)$ of respondents expressed doubt that they have the ability to make the learning process according to curriculum programmed, so that more than half $(64.51 \%)$ of respondents expressed the need to improve their skills in develop instructional materials from local resources.

In the form of work programs are much in demand by the public, the entire (100\%) of respondents stated; Equality Education Unit and Early Childhood Education are the most favored by the public, both held for 3 days a week to provide equal education and 5 days a week for early childhood education, but the majority $(83.87 \%)$ of respondents stated that there are some learner of equal education who can't keep pace with the learning process routinely and regularly. Besides these two education units, the entire (100\%) of respondents also said that literation education is one of the most widely education learners, while the Life Skills Education (LSE) said more than half $(67.74 \%)$ respondents, not too many devotees and a large part $(96.77 \%)$ of respondents said that this program is only carried out when there is a project of the government, therefore, more than half $(67.74 \%)$ of respondents expressed doubt if this program can be done sustainably.

Furthermore, the majority (93.55\%) of respondents said that the CLC has had Community Library that most $(77.42 \%)$ is visited by many readers who are entirely $(100 \%)$ was recorded as learners. In terms of funding for the management of CLC majority (96.68\%) of respondents said they do not have the financial resources of its own, but the majority $(96.68 \%)$ are more reliant on government projects and more than half $(51.62 \%)$ are the dues students $(51.62 \%)$. 
In terms of guidance from the Department of Education and the Ministry of Education and Culture, the majority $(88.71 \%)$ of respondents expressed less gain it, but the whole $(100 \%)$ of respondents agreed that their performance constantly monitored and supervised by officials of the Department of Education and the Ministry of Education and Culture, it is addressing that their skills will always be maintained in order to provide guidance to their subordinates, especially when implementing projects of education offices and projects of Ministry of Education and Culture.

Furthermore, from the existing data can be concluded, each more than half $(74.20 \%)$ of respondents stated that they have not been able to do with a good evaluation, and $74.20 \%$ they do not involve all the components in the CLC, $74.20 \%$ CLC respondents also stated that they had never been evaluated by BAN PNF, so their CLC have not been accredited by BAN PNF. (74.20\%), they also claimed that they do not understand that the results of the evaluation may be recommended to continue the program that is being or has been done, or with remarks such program can be continued with some repair records, or it may also be the result of the evaluation recommendation to terminate the program, but the whole $(100 \%)$ of respondents know that a follow up program is the feedback of the programs that have been implemented, even though they do not understand that a follow up was done in order to continue a program that has not been completed and in order to develop programs elsewhere and approved when acts up of a program carried out in order to improve the system. That statement shows that not all respondents understand the significance and benefits of the planned follow-up of a program.

\section{CONCLUSIONS AND RECOMMENDATIONS}

\section{A. Conclusions}

The results of this study presented conclusions that can be drawn;

- Overall the CLC managers still have a low ability to manage the institution.

- Most CLC has been managing almost all of the programs recommended by the government, especially the Literacy Education, Early Childhood Education, Educational Equality and Community Library.

- Most PKBM do not have its own business units yet that can be used as sources of funding to manage the program, they still rely on to government projects and some small donations from community/learners.
- They are still hoping for more good coaching managerial capabilities of the Department of Education and the Ministry of Education and Culture.

\section{B. Recommendations.}

The manager of CLC should;

- Hasten to create the business entity that can be relied upon to extracting the source of funds, not only rely on the government projects.

- Not only chasing the target of the graduation, but also immediately increasing the quality to turn them into independent beings in many ways, such as in business and independent self and life.

- Encourages learners to be able to learn and try as a group and participatory.

- Asking even more so that the Department of Education and/or the Ministry of Education and Culture to improve the quality of managerial skills of the managers coaching CLC.

\section{REFERENCES}

[1] Departemen Pendidikan Nasional (2003), Undang-undnag Nomor 20 Tahun 2013 tentang Sistem Pendidikan Nasional, Umbara, Bandung.

[2] Setiawan, Wisnu (2010), Peraturan Pemerintah Nomor 66 Tahun of 2010 tentang Perubahan atas Peraturan Pemerintah Nomor 17 tahun 2010 tentang Pengelolaan dan Penyelenggaraan Pendidikan. Jakarta, Sekretariat Negara RI.

[3] Balai Pengembangan Kegiatan Belajar (2002) Modul Pelatihan Peningkatan Keterampilan Manajerial bagi Tenaga kependidikan PKBM Berbasis Mayarakat, BPKB Jaya Giri- UNESCO, Bandung.

[4] Kementrian Pendidikan Nasional (2005), Undang-undang Nomor 14 Tahun 2005 tentang Guru dan Dosen, Umbara, Bandung.

[5] -------------- (2010), Peraturan Pemerintah Rep. Indonesia Nomor 32 tahun 2010 tentang Standar Nasional Pendidikan, Kemendiknas, Jakarta.

[6] Halim, Abdul Karim (2015), Strategi Meningkatkan Rata-rata Lama Sekolah Melalui Pendidikan Nonformal. Bappeda Kab. Bogor - Ibn Khaldun Bogor University. Bogor.

[7] Pramudia, Joni Rahmat and Irfan Hilmi (2015) Prosiding Seminar Nasional tentang Pemetaan Pembangunan Berkelanjutan Abad 21 Untuk Penguatan Peran Pendidikan Nonformal dan Informal di Indonesia, Departemen Pendidikan Luar Sekolah, UPI, Bandung.

[8] Kamil, Mustafa (2009) Pendidikan Nonformal, Alfabeta, Bandung.

[9] Sudjana, Djudju (2010), Pendidikan Nonformal, Fallah Production, Bandung.

[10] ....................... (2000), Manajemen Pendidikan Luar Sekolah, Fallah Productions, Bandung.

[11] Nawawi, Hadari (2002), Metode Penelitian Bidang Sosial, Gajah Mada University, Yogyakarta 